\title{
Macroeconomic conditions for the growth of competitiveness of Russian companies
}

\author{
Alexander Sergeev ${ }^{1}$, Liliya Akhmetshina ${ }^{1, *}$, and Kirill Grabovyy ${ }^{2}$ \\ ${ }^{1}$ Financial University under the Government of the Russian Federation, 125993, Moscow, \\ Leningradsky, 49, Russia \\ ${ }^{2}$ Moscow State University of Civil Engineering, 129337, 26, Yaroslavskoe Shosse, Moscow, Russia
}

\begin{abstract}
Ensuring competitiveness of the Russian companies is the key element among the national priorities of the country. The objective of the research is the definition of macroeconomic conditions for the growth of competitiveness of Russian companies. The achievement of this goal provides the consideration of conditions for the growth of competitiveness of Russian companies at the macroeconomic level, which include the high import dependence, the decrease in the production efficiency and labour productivity, low investment attractiveness and innovative activity, as well as the determination of the priority of the increase in the level of competitiveness of Russian companies. The major circumstance is the transition to the innovative model of economic development, assuming the implementation of technologies on the basis of the advanced knowledge. The susceptibility of the companies to innovations is stimulated by the digital technologies that allow processing huge data arrays and excluding decision-making in the conditions of uncertainty or the lack of information. Company management technologies (such as PLM system, blockchain technologies, Internet of things) are created to improve the conditions of realization of the strategic capacity of the company. Thus, keeping the digital assets gives additional competitive benefits to the companies, and the level of competitiveness of the companies will be defined by the level of their digitalization.
\end{abstract}

\section{Introduction}

The steady growth and stability of the results of the company's activity are impossible without the development of the development strategy, considering its competitive advantages. The competitiveness plays the central role in the modern theory and practice of strategic management. A rather simplified view of competition and competitive advantages (at the price and quality) dominated because of the influence of the classics of economic science for a long time, and the strategy of any company came down to the search of ways and methods of the improvement of the offered goods quality and the decrease in their production costs. Characteristic features of the modern competitiveness and the direction of strategic development of the companies are presented in works of I. Ansoff and M. Porter's

* Corresponding author: akhmetshinalg@mail.ru, angela-1309.m@yandex.ru 
[1-2]. A. Yu. Yudanov and R. A. Fatkhutdinov can be named among the domestic authors developing competitiveness problems. Many problems of the determination and formation of competitiveness of the Russian companies still remain unresolved.

It is necessary to carry out the analysis and the assessment of the competitiveness in connection with the concrete competitive field. Fundamental level of ensuring competitiveness is macroeconomic. At the same time, adequate assessment of deterrents of the macroeconomic environment and search of mechanisms of improving competitiveness of the companies will allow providing the growth of national economy in general [3]. The realization of one's own innovative potential, secondly, digitalization of the companies, acting as the instrument of increase in their innovative activity and competitiveness as well, act as the major conditions. Automation of the existing processes, introduction of cardinally new business models and technologies, including digital platforms, profound analytics of big data arrays, robotizations, Internet of things, etc. will result in the considerable economic effect and growth of competitiveness of Russian companies [4]. The aforesaid circumstances determined the relevance of the conducted research.

\section{Methods}

Competitiveness of the company means the external and internal advantages of the company, allowing it to resist to the competition and to have superiority concerning competitors in one or several spheres of economic interests in a certain market. If the company applies for the worthy strategic status, it needs to have steady competitive advantages, which have long-term character. In this case the strategy of the company is adjusted according to the available potential, volume of capital investments and level of strategic objectives. The assessment of the company competitiveness assumes the determination of private potentials, comparison of potentials for their ranging and calculation of the integrated indicator by various methods.

I. Ansoff suggested to use three relative indicators: indicator of profitability of capital investments for achievement of the goals; indicator of the relative deviation of the actual strategy from optimum; indicator of compliance of the existing optimum opportunities of the company and their realization. The following formula for the determination of the competitive strategic status of the company (Cs) can be used:

$$
\mathrm{Cs}=\Delta \mathrm{Ia} / \Delta \mathrm{Io} * \mathrm{Sat} / \mathrm{Sopt} . * \mathrm{Cap} / \mathrm{Copt}
$$

$\Delta \mathrm{Ia} / \Delta \mathrm{I}$ o - relative deviation of the actual value of capital investments from the critical value, to the deviation of the optimum value from critical;

$\Delta \mathrm{Ia}-(\mathrm{Ca}-\mathrm{Cc})-$ deviation of the actual value of capital investments from critical;

$\Delta \mathrm{Io}-(\mathrm{Copt}-\mathrm{Cc})$ - deviation of the optimum value of capital investments from critical;

$\mathrm{Cc}-$ critical value of capital investments, when the profit is equal to zero in certain operating conditions of the company;

$\mathrm{Sa} / \mathrm{So}$ - relative deviation of the actual purposes from the optimum strategy;

$\mathrm{Ca} / \mathrm{Co}-$ relative deviation of realization of the actual value in comparison with the realization of optimum value of the potential or opportunities of the company.

The indicator of the competitive strategic status is ranging from 0 up to 1; the higher the probability of success and leadership in this competitive market, the higher the competitive status of the company. The zero value of at least one indicator will result in the insolvency and non-competitiveness of the company. Thus, the problem of determination of strategic potential comes down to the determination of the sufficiency of capacity of the company for achievement of the goals and definition of the extent of preference of environmental conditions. The solution of the first task is put in the potential of the company: marketing, 
management, innovative, resource, production and marketing. The set of the strategic resources, making the capacity of the company, can qualitatively change in case of adoption of the cardinal decisions, based on the new knowledge, changing the structure and quality of the main processes in the company. As for the optimal conditions of the external environment for the strategy realization, if they are better, the smaller size of potential is necessary for the company for achievement of the strategic objectives.

It should be noted, that the existing macroeconomic conditions determining the efficiency of realization of capacity of the companies act as the obstacle for the growth of competitiveness of Russian companies and for the development of national economy in general.

The technique of the carried out research assumes complex consideration of the macroeconomic factors, preventing the growth of competitiveness of the Russian companies. It is proved further, that the level of competitiveness of the companies will be defined by the level of innovative activity and implementation of digital technologies in modern conditions. It is offered to consider the impact of digitalization on the conditions of realization of the strategic capacity of the company when determining competitiveness of the companies, when it is necessary to improve the formula of calculation of the integrated indicator of the competitive strategic status of the company. The factorial analysis allowed pointing out the priorities of the increase in the level of competitiveness of the companies at the macroeconomic level.

\section{Results}

In recent years, Russia achieved relative success in the improvement of macroeconomic environmental conditions of the companies. According to the Report of the World Economic Forum (WEF) On global competitiveness in 2017-2018 [5], Russia rose by 5 lines in the rating of the countries by the Index of global competitiveness in comparison with the previous year and took the 38th place among 137 countries. Russia takes quite good positions according to such indicators as the market volume, higher education and vocational training, infrastructure, innovative potential, the macroeconomic environment, health, technological level, efficiency of labour market and information-andcommunication technologies. At the same time, the indicator of growth of added value of the information-and-communication technologies (ICT) in the gross domestic product (GDP) is the necessary condition of the development of digital technologies and growth of competitiveness of Russia. According to the indicator of technological readiness of the country in the rating of the Index of global competitiveness 2017-2018, Russia took the 57th place [6]. Russia was in the lower half of rating according to such composed competitiveness as competitiveness of the companies (71st place), efficiency of commodity market and services (80th place), public institutes (83rd place) and development of the financial market (107th place). Monopolism, corruption remain the weaknesses of the Russian economy. As the result we can notice low competitiveness of the companies and their products [7].

The determining indicator of the national economy growth is the growth rate of GDP (figure 1) [8-9]. 


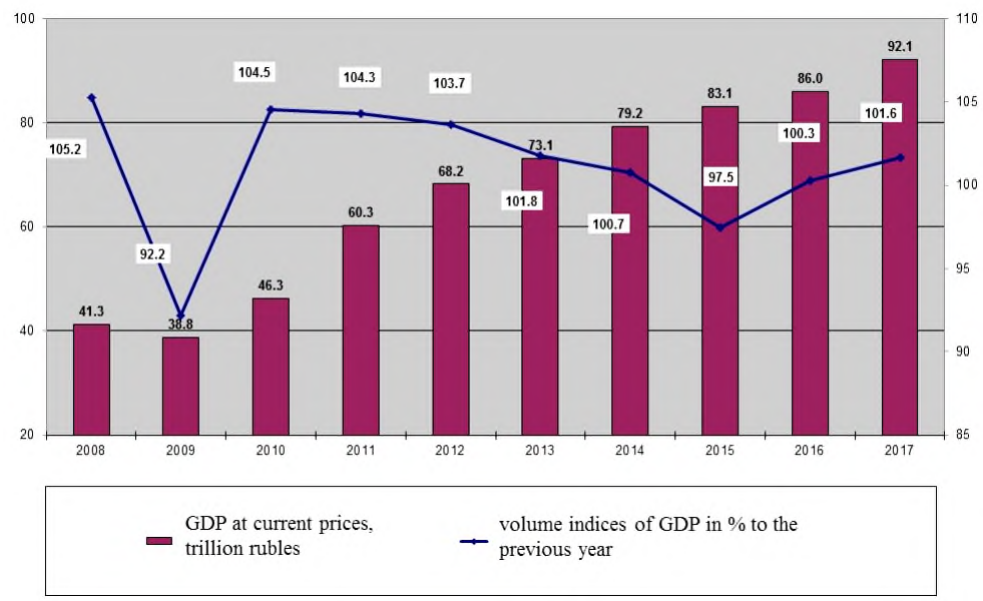

Fig. 1. Dynamics of GDP in Russia in 2008-2017

The dynamics of GDP in Russia demonstrates sharp rises and falling caused by the political situation and the global financial crises. The highest growth rates of GDP in the ten-year period were observed in Russia during 2010-2012. The favourable market conditions, high prices of hydrocarbons provided average growth rate of GDP, which was $4.2 \%$. But at the same time, according to the International Monetary Fund (IMF), in 20082017 the Russian economy grew by $6 \%$, whereas the world economy grew on average by $35 \%$. The developed economies showed the growth rates on average twice above the growth rate of the Russian economy. And growth rates of the developing economies surpassed it on average more than by 7 times [10].

In 2014 the sanctions against Russia, imposed by the West, devaluation of rouble, aggravated the problems of production efficiency of products in Russia. The decrease in profitability of assets and profitability of sales put the solution of two opposite problems: the growth of own low effective production with great investments (import substitution) or growth of import and increase in level of the dependence on the foreign capital.

The monitoring of the economic situation in Russia in 2015 proved high import dependence of the companies in many industries (table 1) [11].

Table 1. Import dependence of the companies in the branches of processing industry in 2015

\begin{tabular}{|l|c|}
\hline & Share of import in the prime cost, $\%$ \\
\hline Processing industry in general & $13-31$ \\
\hline Textile production & $15-34$ \\
\hline $\begin{array}{l}\text { Wood processing, production of products from } \\
\text { wood }\end{array}$ & $4-24$ \\
\hline Pulp-and-paper production & $21-40$ \\
\hline Chemical production & $16-35$ \\
\hline Metallurgical production & $6-22$ \\
\hline Production of machines and equipment & $10-28$ \\
\hline $\begin{array}{l}\text { Production of the electronic and optical } \\
\text { equipment }\end{array}$ & $19-37$ \\
\hline Production of cars & $22-41$ \\
\hline Production of other vehicles and equipment & $6-21$ \\
\hline
\end{tabular}

The priority directions of ensuring the economic growth and improving competitiveness are the growth of industrial production and its specific weight in GDP as well as the 
increase in the production efficiency, including labour productivity. While the indicator of gross added value of processing industry in 2008-2016 shows positive dynamics, its specific weight in GDP fluctuates at the level of $12 \%$. There is a decline in the production of work in the processing industry (fig. 2) [12]. It is remarkable, that the developed countries have the industrial share in GDP of the country of about $30 \%$; that allows them to have high percent of updating of the equipment and to make products on innovative technologies, providing the entry into the world market. The countries in which the industry share is small (including Russia) are deprived of such an opportunity.

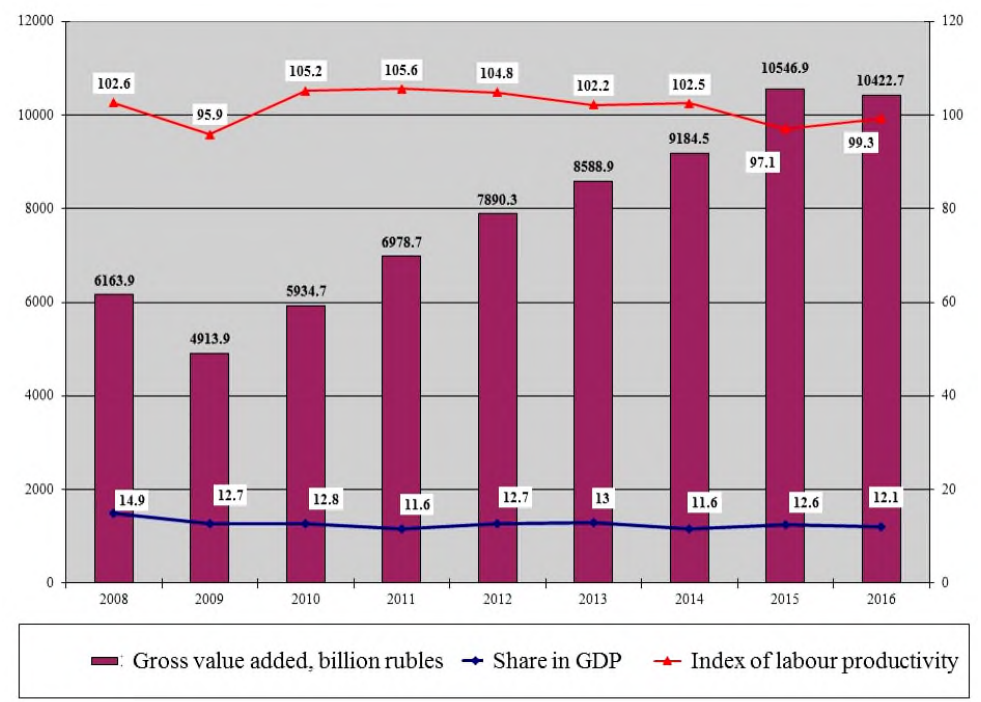

Fig. 2. Dynamics of gross added value of the processing industry in Russia, the share in GDP and labour productivity in 2008-2016

New hi-tech, automated manufacturing lines demanding considerable capital investments are necessary for more advantageous position in production. However, private foreign and domestic investors are not ready to put money at risk in such "adverse climate" as Russia. The low investment attractiveness is caused by negative impact of sanctions and also the decrease in internal consumption, which leads to falling of production and reduction of internal solvency. The high product cost, wear of fixed assets (more than $50 \%$ ) are additional problems. There is no investment boom in the country, and the forecast is not consolatory.

The leaders of competitiveness among the countries of the world are also characterized by leadership in the innovative component of competitiveness. The goods, manufactured on the hi-tech equipment, are in multifunctional, have more perfect design, their cost for the producer is cheaper, than the cost of traditional samples [13]. Thus, they are attractive to consumers and they are in great demand, their sale brings high added value. The developed economy is formed in the innovative sphere: the new productive equipment allows creating cost due to the technologies and production of means of production, consuming less than the cost of raw materials and import accessories $[14,15]$.

The heads of the companies in Russia seldom show an initiative and activity in introduction of innovations. It is explained by insufficient demand, the lack of financial resources, low level of the personnel qualification, high risk level. The share of the companies of processing industry, which are carrying out technological innovations, makes $13.7 \%$ of their total. The share of costs of the technological innovations in the total amount 
of production costs of the shipped goods, performance of work, rendering services of the companies of the industrial production of Russia makes 1.9\% (fig. 3) [16].

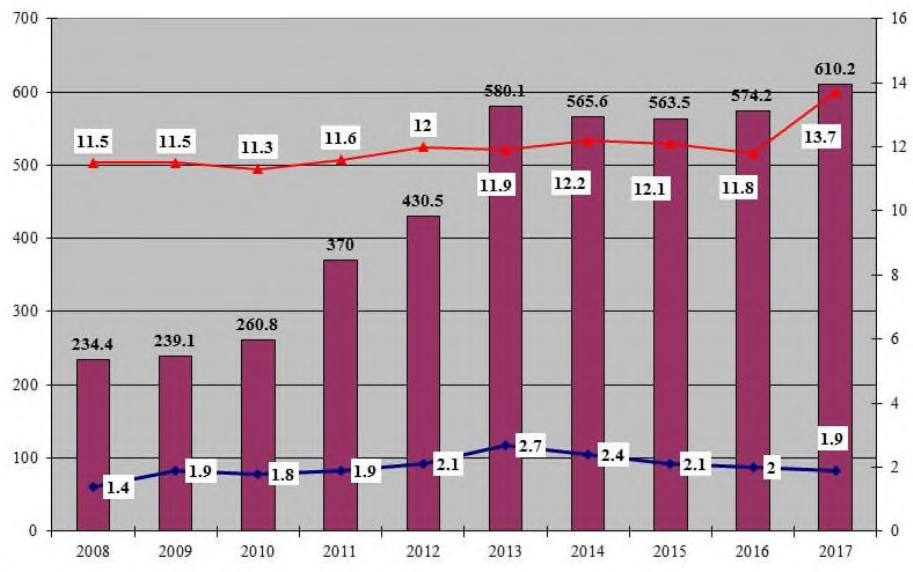

$$
\begin{aligned}
& \text { Expenses on technological innovations of organizations, billion rubles } \\
& \text { - Share of costs for technological innovations in the total volume of goods } \\
& \text { - shipped, performed works, services, } \%
\end{aligned}
$$

Fig. 3. Dynamics of indicators of innovative activity in processing industry in 2008-2017

Having generalized all the above-mentioned circumstances, among the major constraining macroeconomic factors of the competitiveness growth of the Russian companies, it is necessary to point out:

- import dependence of the companies of processing industry, first of all - dependence on import of machines and the equipment, due to the lack of analogs, technologies and services in domestic market, and in case of their existence, owing to poor quality of the domestic offer and its discrepancy to the production requirements of customers;

- low efficiency of industrial production and labour productivity, which do not allow carrying out continuous updating of the equipment and technologies, determining the conditions of production of competitive products;

- insufficient investment attractiveness and innovative activity of the Russian economy. The investments into economy in the comparable prices fall because of reduction of own investments at the expense of the profit of the companies and reduction of foreign investment owing to insufficient domestic solvent demand, negative impact of sanctions. In turn, the limitation of investment resources affects the opportunities of the implementation of innovative projects.

In modern conditions, the main factor of economic growth of national economies, industries and companies is the implementation of technologies on the basis of the advanced knowledge, which is based on the development of artificial intelligence, digital economy, the possibility of storage and processing of large volume of information. Russia goes on the way of acquisition and adaptation of new foreign technologies and creation of our own developments [17].

Nowadays, the digital technologies allow processing huge data arrays, both according to the market conditions of realization of an innovative product, and to the strategic capacity of the company. The latest developments of digital complexes include maintenance, satellite navigation, digital sight and control of processes. Advantages of new technologies are that control systems already depend on a subjective factor to a lesser extent, and 
decision-making in the conditions of uncertainty or the lack of information is excluded. At the first stage of digitalization of the industry, the efficiency of introduction will be determined by the possibility of adaptation and retrofitting of the operating robotic lines with the program complexes of management, touch sensors and other electronic devices, providing regulation, control and monitoring of business processes.

Company management technologies (PLM system, blockchain technologies, technologies of Internet of things, 3D-technologies) are designed to improve conditions of realization of strategic capacity of the company. Long process of the technical ideas development, design-technology preparation slow down the whole cycle of introduction of a new product and its entry into the market. Unfortunately, software products of the automated design of products came to us much later, and the conditions for their introduction ripened just now. For example, Product Lifecycle Management (PLM) is considered in the West as the strategic approach to business. It is important to note that PLM creates the common information space for the staff of the company, there is an exchange of information not only among various blocks, the external environment, but also among the adjacent control systems of products and project managements. The decrease in prime cost by product unit, the increase in labour productivity, reduction of duration of preparation for production and performance of production operations became the most important achievement of introduction of these systems. Strategic approach to Product Lifecycle Management increases the quality of products and degree of satisfaction of consumers [18].

Thus, possession of digital assets gives additional competitive benefits to the companies, and the level of competitiveness of the companies will be determined by the level of their digitalization $[19,20]$. The strategic competitiveness of the company is offered to be determined by the work not of three, but four relative coefficients, including the coefficient, reflecting the impact of digitalization on conditions of realization of strategic capacity of the company:

$$
\mathrm{Cs}=\Delta \mathrm{Ia} / \Delta \mathrm{Io} * \mathrm{Sat} / \mathrm{Sopt} .{ }^{*} \mathrm{Cap} / \mathrm{Copt} .{ }^{*} \mathrm{Cdt}
$$

$\mathrm{Cdt}-(\mathrm{Na} . / \mathrm{Nop})$ - coefficient of the use of digital technologies;

$\mathrm{Na}$-actual quantity of the key processes, covered by digitalization, from the concept of the product creation to its disposal;

Nop-optimal quantity of digitalization of the main processes, from the concept of the product to its disposal.

The reduction of duration, the increase in the efficiency of processes and their productivity will increase the speed of passing of innovative goods from the design stage before consumption due to the implementation of modern technologies and will increase the competitiveness of the companies.

\section{Conclusions}

The following measures are necessary for ensuring the growth of competitiveness of Russian companies:

- to direct the assets to import substitution and creation of the hi-tech real sector of production of the means of production of the fifth and sixth technological mode. Significant advance of information services and implementation of digital technologies in the industry of Russia can be expected only after the solution of some critical problems of the economy: import substitution and replacement of the outdated equipment, the increase in financing of innovative business; 
- to increase the productivity and efficiency of industrial production due to digitalization. The labour productivity in the next years will increase due to the optimization of structural divisions of the companies and reduction of quantity of workers of low qualification, reduction of time of life cycle of products and the increase in the efficiency at all its stages;

- to create the multiplicative effect of implementation of digital technologies, first of all, in the industry. At the present stage, fast rapprochement of all the directions of digital economy occurs: the artificial intelligence, 3D - technologies, cloud computing, blockchain, etc., besides, their fast distribution to the allied industries occurs.

Thus, particular importance in structure of GDP has to be attached to the development of ICT and to the increase in specific weight of added value of ICT for improving the competitiveness of Russian companies. When determining the strategic status of the company, it is necessary to consider the efficiency of digital technologies influencing the main processes of added value of products, and the increase in the company value.

\section{References}

1. I. Ansoff, Strategic management (Moscow, Economy, 1989)

2. M. Porter, Competition (Williams publishing house, Moscow 2010)

3. D. G. Castorena, G. R. Rivera, A. V. González, Foresight, 15(6), 492-516 (2013)

4. N. Smorodinskaya, The globalized economy: from hierarchies to network way (Moscow, IE RAS, 2015)

5. M. A. Bahauovna, M. A. Bahauovna, International Journal of Applied Engineering Research, 10(23), 43446-434499 (2015)

6. G. I. Abdrakhmanova, K. O. Vishnevsky, G. L. Volkova, L. M. Gokhberg, et al., Indicators of digital economy: 2018: statistical collection (Moscow, Higher School of Economics National Research University, 2018)

7. J. F. Coates, Technological Forecasting and Social Change, 77(9), 1428-1437 (2010)

8. E. Vasilyeva, MATEC Web of Conferences, 193, 01025 (2018), DOI: https://doi.org/10.1051/matecconf/201819301025

9. A. Mottaeva, IOP Conf. Series: Earth and Environmental Science, 90, 012120 (2017) doi: 10.1088/1755-1315/90/1/01212010.

10. Y. Simachev, M. Kuzyk, N. Zudin, Foresight, STI Governance, 10(4), 25-45 (2016)

11. A. Mottaeva, MATEC Web of Conferences, 193, 01022 (2018)

12. Y. Sheffi, J. B. Rice, MIT Sloan Management Review, 47(1), 41-48 (2005)

13. Y. V., Morozyuk, A. V., Sharkova, I. A., Merkulina, O. N. Vasilyeva, Journal of Environmental Management and Tourism, 8, 3(19), 507-515 (2017)

14. M. E. Konovalova, O. Yu. Kuzmina, K. Yu. Surikov, Economy and property management, 4, 5-9 (2017)

15. R. Hernandez, C. Fernandez, M. P. Baptista, Metodología de la investigación (México, McGraw Hill, 2014)

16. L. Rivest, A. Bouras, B. Louhichi, IFIP AICT 388, 134-146 (2012) 
17. M. Nenni, V. P. Arnone, et al., International Journal of Engineering Business Management, 6(8), 1-7 (2014)

18. R. Horne, Global Construction Success (2018) DOI: 10.1002/9781119440345.ch20

19. V. V. Zozulya, L. I. Goncharenko, A. V. Zuikov, G. N. Semenova, Journal of Advanced Research in Law and Economics, 8(5) (2017)

20. E. Akhmetshin, J. Mueller et al., Journal of Entrepreneurship Education, 21(1) (2019) 